\title{
New advances in plant growth-promoting rhizobacteria for bioremediation
}

\author{
Xuliang Zhuang ${ }^{\mathrm{a}, *}$, Jian Chen ${ }^{\mathrm{b}}$, Hojae Shim ${ }^{\mathrm{c}}$, Zhihui Bai ${ }^{\mathrm{b}}$ \\ ${ }^{a}$ Bureau of Science and Technology for Resources and Environment, Chinese Academy of Sciences, No. 52, Sanlihe Rd., Xicheng District, Beijing 100864, China \\ b Department of Environmental Biotechnology, Research Center for Eco-Environmental Sciences, \\ Chinese Academy of Sciences, P.O. Box 2871, Beijing 100085, China \\ ${ }^{\mathrm{c}}$ Department of Civil and Environmental Engineering, Faculty of Science and Technology, University of Macau, Macau 999078, China
}

Received 18 August 2006; accepted 18 December 2006

Available online 1 February 2007

\begin{abstract}
Plant growth-promoting rhizobacteria (PGPR) are bacteria capable of promoting plant growth by colonizing the plant root. For a long period PGPR were mainly used for assisting plants to uptake nutrients from the environment or preventing plant diseases. Phytoremediation is a new and promising approach to remove contaminants in the environment. But using plants alone for remediation confronts many limitations. Recently, the application of PGPR has been extended to remediate contaminated soils in association with plants. Of all the present contaminants, the profound impacts of organic and heavy metal pollutants have attracted world wide attention. Here we review the progress of PGPR for remediation of soils contaminated with these two sources.
\end{abstract}

(C) 2007 Elsevier Ltd. All rights reserved.

Keywords: Bioremediation; Heavy metals; Organic contaminants; Plant growth-promoting rhizobacteria (PGPR)

\section{Contents}

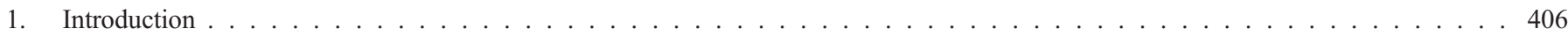

2. Remediation of organic contaminants by PGPR . . . . . . . . . . . . . . . . . . . . . . . 407

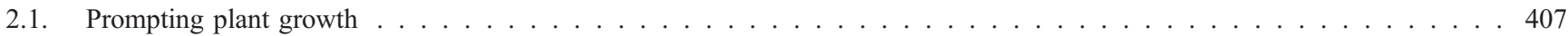

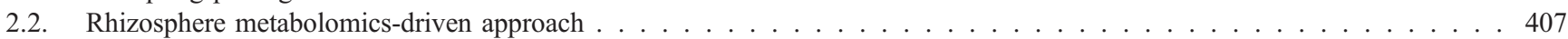

2.3. Genetically-engineered rhizobacteria . . . . . . . . . . . . . . . . . . . . . . . 408

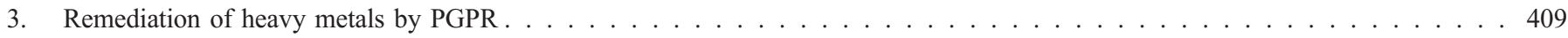

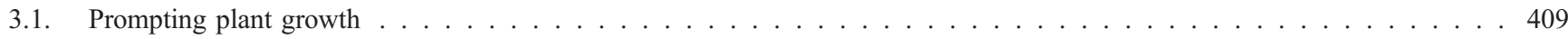

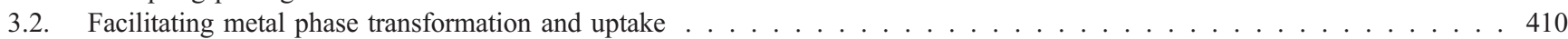

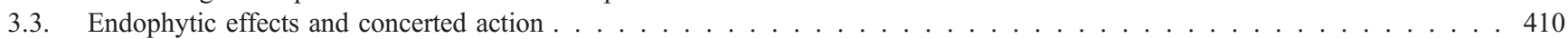

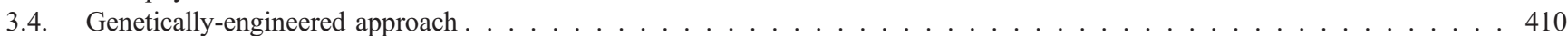

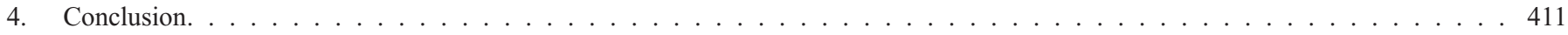

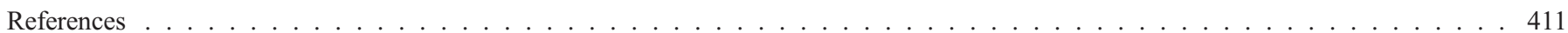

\section{Introduction}

Plant growth-promoting rhizobacteria (PGPR) are bacteria capable of promoting plant growth by colonizing the plant root (Kloepper and Schroth, 1978). PGPR can be divided into two

\footnotetext{
* Corresponding author. Tel./fax: +86 1068597540 .

E-mail address: xlzhuang@cashq.ac.cn (X. Zhuang).
}

groups according to their relationship with the plants: symbiotic bacteria and free-living rhizobacteria (Khan, 2005). As reviewed by Compant et al. (2005), Glick (1995, 2001), Hall (2002), Hallman et al. (1997), Lucy et al. (2004), Sturz et al. (2000), and Welbaum et al. (2004), a lot of work have been done on the mechanisms and principles of the PGPR-plant relationship, which was accepted widely as rhizosphere effect. Generally, PGPR function in three different ways (Glick, 1995, 
2001): synthesizing particular compounds for the plants, facilitating the uptake of certain nutrients from the environment (Çakmakçi et al., 2006; Lucas García et al., 2004a,b; Siddiqui and Mahmood, 2001), and lessening or preventing the plants from diseases (Guo et al., 2004; Jetiyanon and Kloepper, 2002; Raj et al., 2003; Saravanakumar et al., in press).

The fast industrialization and modernization all around the world leads to an unfortunate consequence: the production and release of considerable amounts of toxic wastes to the environment. According to the Environmental Protection Agency (EPA) report (see http://www.epa.gov/superfund/sites/phonefax/ products.htm), the United States was with more than 40,000 contaminated sites as of May 2004. Some industrialized countries in Western Europe possess even more contaminated sites in a comparatively small area (Prokop et al., 2000). In order to eliminate or control the pollutants in soils, physical, chemical, and biological methods have been employed. Bioremediation is the application of biological processes for the cleanup of hazardous chemicals present in the environment (Gianfreda and Rao, 2004). It has obvious advantages over physicochemical remediation methods due to several merits: cost-effective, convenient, complete degradation of organic pollutants, and no collateral destruction of the site material or its indigenous flora and fauna (Timmis and Pieper, 1999). As reviewed by Lucy et al. (2004), although the extensive use of PGPR for the environmental remediation with plants emerged as a promising field, there have been only very few field studies while most are controlled studies conducted in greenhouses and/or growth chambers.

Some organic contaminants can persist in the environment for a long time and bring great threat to human health. They mainly include: total petroleum hydrocarbons (TPHs) and polycyclic aromatic hydrocarbons (PAHs) coming from the exploration and consumption of fossil fuel, polychlorinated biphenyls (PCBs) widely used in the industrial process and are most degradation-resistant, and other chlorinated aromatics used as PCB replacement such as polychlorinated terphenyls (PCTs), halogenated compounds like perchloroethylene (PCE) and trichloroethylene (TCE) and pesticides like atrazine and bentazon. (Saleh et al., 2004). Heavy metals are the primary inorganic contaminants, which include cadmium, chromium, copper, lead, mercury, nickel and zinc etc. This article reviews the applications of PGPR for bioremediation of these two main kinds of contaminants respectively.

\section{Remediation of organic contaminants by PGPR}

Although PGPR was first used for prompting the plant growth and for the biocontrol of plant diseases, much attention has recently been paid on bioremediation with PGPR (Huang et al., 2004b, 2005; Narasimhan et al., 2003). In contrast with inorganic compounds, microorganisms can degrade and even mineralize organic compounds in association with plants (Saleh et al., 2004). Hence discovery of effective pathways for degradation and mineralization of organic compounds may play an important role in the future. So far, bacteria capable of degrading certain kind of organic pollutant, such as polychlorinated biphenyls (PCBs) have been isolated from a range of sites and the pathways and encoding genes have also been well studied (Brazil et al., 1995). But most of these bacteria cannot survive in the near-starvation conditions found in soils, including the rhizosphere (Normander et al., 1999). Recent examples of bioremediation of organic contaminants by PGPR are shown in Table 1. Several effective methods have been developed to improve the degradation efficiency and the tolerance of bacteria to contaminants in soils.

\subsection{Prompting plant growth}

Compared with physical and chemical remediation, phytoremediation has several advantages: (1) it preserves the natural properties of soil; (2) it acquires energy mainly from sunlight; (3) high levels of microbial biomass in the rhizosphere can be achieved; (4) it is low in cost; and (5) it has the potential to be rapid (Huang et al., 2004b). Although with these advantages, some plants show very low tolerance to the soil contaminants, which limits the degradation efficiency to an insufficient level for the meaningful soil remediation.

According to Huang et al. (2004a,b), the addition of PGPR increased the organic pollutant (polycyclic aromatic hydrocarbon and creosote) removal probably by enhancing plants germination and survival in soils that were heavily contaminated and by stimulating the plants to grow faster and accumulate more root biomass. Ethylene is important for plant growth (Deikman, 1997), while excessive ethylene promoted by stresses can depress growth (Morgan and Drew, 1997). PGPR have a positive effect on plant growth by consuming amino-cyclopropane carboxylic acid (ACC), the immediate precursor to ethylene, through synthesis of 1-aminocyclopropane-1-carboxylate deaminase (ACC deaminase) to decrease the ethylene production in stressed plants (Hall et al., 1996; Reed and Glick, 2005; Safronova et al., 2006).

Facing a variety of environmental contaminants such as total petroleum hydrocarbons (TPHs), remediation technology even with both PGPR and plants may still be low in efficiency. The combination of PGPR and specific contaminant-degrading bacteria was found to be effective (Ajithkumar et al., 1998). Huang et al. (2005) thus developed a multi-process phytoremediation system (MPPS). They used both PGPR and specific contaminant-degrading bacteria to treat TPHs. In this system, specific contaminant-degrading bacteria can be selected according to the properties of contaminants. They can rapidly metabolize some readily available compounds while the role of PGPR is still prompting plant growth and increasing the plant tolerance to pollutants.

\subsection{Rhizosphere metabolomics-driven approach}

As described above, although rhizobacteria may play an important role in the degradation and mineralization of organic compounds, the metabolic efficiency can be very low. Possible causes may be the small microbial biomass or the low solubility and bioavailability under high toxic pressure (Liste and Alexander, 2000). One solution is the employment of plant exudates to promote bacterial degradation. 
Table 1

Examples of bioremediation of organic contaminants by PGPR

\begin{tabular}{|c|c|c|c|c|c|}
\hline Bacteria & Plant & Organic contaminant & Condition & Role of PGPR & Reference \\
\hline $\begin{array}{l}9 \text { Azospirillum } \\
\text { lipoferum strains } 15\end{array}$ & Wheat & Crude oil & $\begin{array}{l}\text { Pot experiments in } \\
\text { growth chamber }\end{array}$ & - Promoted development of wheat root system & Muratova et al. (2005) \\
\hline $\begin{array}{l}9 \text { unidentified } \\
\text { azospirilla }\end{array}$ & & & & - Enhanced level of oil degradation & \\
\hline \multicolumn{6}{|l|}{$\begin{array}{l}\text { Azospirillum } \\
\text { brasilense strains }\end{array}$} \\
\hline $\begin{array}{l}\text { Azospirillum } \\
\text { brasilense } \mathrm{Cd}\end{array}$ & Tall fescue & $\begin{array}{l}\text { Polycyclic aromatic } \\
\text { hydrocarbons (PAHs) }\end{array}$ & $\begin{array}{l}\text { Pot experiments in } \\
\text { growth chamber }\end{array}$ & - Increased plant tolerance to PAHs & Huang et al. (2004b) \\
\hline $\begin{array}{l}\text { Enterobacter cloacae } \\
\quad \text { CAL } 2\end{array}$ & & & & - Promoted plant growth under stress & \\
\hline \multicolumn{6}{|l|}{$\begin{array}{l}\text { Pseudomonas putida } \\
\text { UW3 }\end{array}$} \\
\hline $\begin{array}{l}\text { Enterobactor cloacae } \\
\quad \text { CAL2 }\end{array}$ & Tall fescue & $\begin{array}{l}\text { Total petroleum } \\
\text { hydrocarbons (TPHs) }\end{array}$ & $\begin{array}{l}\text { Pot experiments in } \\
\text { growth chamber }\end{array}$ & $\begin{array}{l}\text { - Promoted plant growth in the presence of } \\
\text { environmental contaminants such as TPHs }\end{array}$ & Huang et al. (2005) \\
\hline \multicolumn{6}{|l|}{$\begin{array}{l}\text { Enterobactor cloacae } \\
\quad \text { UW4 }\end{array}$} \\
\hline $\begin{array}{l}\text { Pseudomonas } \\
\quad \text { fluorescens } 2-79\end{array}$ & Wheat & Trichloroethylene (TCE) & $\begin{array}{l}\text { Pot experiments in } \\
\text { growth chamber }\end{array}$ & - Degraded TCE with toluene $o$-monooxygenase & Yee et al. (1998) \\
\hline $\begin{array}{l}\text { Pseudomonas } \\
\quad \text { fluorescens } \mathrm{F} 113\end{array}$ & Alfalfa & $\begin{array}{l}\text { Polychlorinated biphenyls } \\
\text { (PCBs) }\end{array}$ & $\begin{array}{l}\text { Pot experiments in } \\
\text { growth chamber }\end{array}$ & $\begin{array}{l}\text { - More effectively metabolized PCBs with } \\
b p h \text { gene cloned }\end{array}$ & Villacieros et al. (2005) \\
\hline $\begin{array}{l}\text { Pseudomonas putida } \\
\quad \text { Flav1-1 }\end{array}$ & Arobidopsis & PCBs & $\begin{array}{l}\text { Pot experiments in } \\
\text { growth chamber }\end{array}$ & - Utilized plant secondary metabolites & Narasimhan et al. (2003) \\
\hline $\begin{array}{l}\text { Pseudomonas putida } \\
\quad \text { PML2 }\end{array}$ & & & & - Direct degradation of PCBs & \\
\hline
\end{tabular}

Although PCB-degrading bacteria are found ubiquitously in the environment, the majority of them are still inefficient in degrading PCBs (Donnelly et al., 1994), due to the rare bacterial population resulting from the lack of sustaining nutrients. Some plants can release structural analogs of PAHs, such as phenols, to promote the growth of hydrocarbon degrading-microbes and their degradation on PAHs (Fletcher and Hedge, 1995). The strategy of Narasimhan et al. (2003) for increasing the microbial biomass in rhizosphere is also using the natural secondary metabolites exuded by wild-type plants. By establishing the Arabidopsis-Pseudomonas spp. rhizosphere model, plant secondary metabolites were exuded in sufficient amounts to establish a rhizosphere specific to the rhizobacterial strain capable of metabolizing phenylpropanoids. Also, they indicated in cases where the pollutant-degrading microbes are not known to use secondary metabolites, such characteristics could be introduced into them using genetic-engineering methods. Similarly, Chekol et al. (2004) reported reed canarygrass and switchgrass effectively increased microbial dehydrogenase activity on the degradation of high level of Aroclor 1248, a kind of PCB.

Introduction of other inoculants is another method. Several researchers reported inoculation of bacteria into rhizosphere for the degradation of certain kind of chlorobenzoates and pesticides (Alvey and Crowley, 1996; Crowley et al., 1996; Siciliano and Germida, 1997). But the mechanisms are not clear. Siciliano and Germida (1999) investigated Dahurian wild rye (Elymus dauricus) inoculated with Pseudomonas aeruginosa strain R75 and P. savastanoi strain CB35 for the degradation of different kinds of chlorobenzoates such as 2-chlorobenzoic acid (2CBA), 3-chlorobenzoic acid (3CBA), 2,3-dichlorobenzoic acid (23diCBA) and 2,5-dichlorobenzoic acid (25diCBA). They found that inoculants capable of degrading 2CBA can also promote 3CBA degradation but have no effect on $23 \mathrm{diCBA}$ and 25diCBA, which suggested the different pathway between them. Besides, when inoculated these two bacteria in a sterile hydroponic plant growth system, no effect on contaminants was detected. So they hypothesized that inoculants increased degradation of contaminants by affecting the rhizosphere community and the plants provided a suitable habitats for this process.

\subsection{Genetically-engineered rhizobacteria}

The rhizosphere seems to be a promising environment for the bioremediation of contaminated soils, but as described above, many bacteria capable of degrading certain kinds of organic pollutants cannot survive and achieve bioremediation in the soil environment, because they are not competitive enough compared to other indigenous organisms. Meanwhile, many bacteria that are robust in the rhizosphere do not show or show only limited ability in degrading organic pollutants. With the development of molecular biology, the genetically-engineered rhizobacteria with the contaminant-degrading gene are constructed to conduct the bioremediation in rhizosphere.

For some pollutants such as trichloroethylene (TCE) (Bradford, 1976) and PCBs (Brazil et al., 1995), the molecular mechanisms of degradation have been clearly studied. Another crucial problem to be solved is to select a suitable strain for gene recombination and inoculation into the rhizosphere. The following criteria should be considered: (1) the strain should be stable after cloning and the target gene should have a high expression; (2) the strain should be tolerant or insensitive to the contaminant; and (3) some strains can survive only in several specific plant rhizosphere (Brazil et al., 1995; Yee et al., 1998). 
Other methods are also considered besides the strain selection. For example, Villacieros et al. (2005) reported that the expression level of the bph genes in Pseudomonas fluorescens F113 was lower than that in the parental strain, which limited the ability of F113 to grow on biphenyl and therefore limited its ability to degrade PCBs. They found a way of increasing the biphenyl-degrading activity by increasing the transcription rate of the genes by changing the promoter regions. The heterologous rhizobial nodulation promoters (nod boxes) from Sinorhizobium meliloti and its regulatory systems were thus tested to drive the expression of the bph operon in P. fluorescens F113 derivatives.

Barac et al. (2004) constructed the engineered endophytic bacteria to improve the phytoremediation of water-soluble, volatile, organic pollutants. The genetically modified endophytic strain showed the improved degradation and reduced the evapotranspiration of toluene, a moderately hydrophobic volatile compound. They hypothesized that the endophytic bacteria, possessing the genetic information required to efficiently degrade the organic contaminant, promoted its breakdown as it moved through the plant's vascular system. Due to the long transportation time of contaminant in the system, there was a sufficient time for the efficient degradation by endophytic bacteria in xylem.

\section{Remediation of heavy metals by PGPR}

Phytoremediation of heavy metals includes phytoextraction, rhizofitration, phytostabilization and phytovolatilization (Glick, 2001). A number of plants which can tolerate and accumulate high concentration of metals were discovered recently and were defined as hyperaccumulators. Ideal hyperaccumulators for bioremediation require the characteristics of rapid growth and a high amount of biomass (Nie et al., 2002). But in fact, many hyperaccumulators are slow in growth and inhibited in the presence of high concentration of heavy metals. On the other hand, the heavy metal contamination has great effects on the microbial communities in soils in several ways: (1) it may lead to a reduction of total microbial biomass (Brookes and
McGrath, 1984; Fliessbach et al., 1994); (2) it decreases numbers of specific populations (Chaudri et al., 1993; Koomen et al., 1990); or (3) it makes shifts in the microbial community structure (Frostegård et al., 1993, 1996; Gray and Smith, 2005). Sandaa et al. (1999) suggested that the presence of even small amounts of heavy metals caused a substantial reduction in the total bacterial diversity.

Due to the sensitivity and the sequestration ability of the microbial communities to heavy metals, microbes have been used for bioremediation (Hallberg and Johnson, 2005; Kao et al., 2006; Umrania, 2006). Although microbial communities in metal-polluted bulk soils have been studied, there is little information on the composition of microbial community in the plant rhizosphere growing in soils highly polluted with heavy metals (Dell'Amico et al., 2005). The rhizosphere, with high concentration of nutrients exuded from the roots, attracts more bacteria than in the bulk soils (Penrose and Glick, 2001). These bacteria (including PGPR), in reverse, facilitate the growth of the plant. This phyto-bacteria system is proved to be more effective in removing heavy metals than its ingredients. Recent examples of the bioremediation of heavy metals by PGPR are shown in Table 2.

\subsection{Prompting plant growth}

Just like the character of PGPR in the remediation of organic compounds, they can also prompt plant growth by the synthesis of ACC deaminase (Belimov et al., 2005; Burd et al., 1998; Reed et al., 2005; Safronova et al., 2006). PGPR with ACC deaminase were isolated from rhizosphere of various plants (Belimov et al., 2001). What's more, some rhizobacteria can promote plant growth by the synthesis of other compounds, such as siderophores, indole-3-acetic acid (IAA) and antibiotics with heavy metal contaminants, which is different from organic pollutants (Burd et al., 2000; Glick, 2001; Pattern and Glick, 1996) or though stimulation of certain metabolic pathways such as nitrogen fixation and the uptake of nitrogen, phosphorus, $\mathrm{S}$, $\mathrm{Mg}, \mathrm{Ca}$ and other nutrients (Bashan and Levanony, 1990; Belimov and Dietz, 2000; Okon and Labandera-Gonzalez,

Table 2

Examples of bioremediation of heavy metals by PGPR

\begin{tabular}{|c|c|c|c|c|c|}
\hline Bacteria & Plant & Heavy metal & Condition & Role of PGPR & Reference \\
\hline $\begin{array}{l}\text { Azotobacter chroococcum } \mathrm{HKN}-5 \\
\text { Bacillus megaterium } \mathrm{HKP}-1 \\
\text { Bacillus mucilaginosus } \mathrm{HKK}-1\end{array}$ & $\begin{array}{l}\text { Brassica } \\
\text { juncea }\end{array}$ & Lead, zinc & $\begin{array}{l}\text { Pot experiments in } \\
\text { greenhouse }\end{array}$ & $\begin{array}{l}\text { - Stimulated plant growth } \\
\text { - Protected plant from metal toxicity }\end{array}$ & Wu et al. (2006b) \\
\hline Bacillus subtilis $\mathrm{SJ}-101$ & $\begin{array}{l}\text { Brassica } \\
\text { juncea }\end{array}$ & Nickel & $\begin{array}{l}\text { Pot experiments in } \\
\text { growth chamber }\end{array}$ & - Facilitated Ni accumulation & Zaidi et al. (2006) \\
\hline $\begin{array}{l}\text { Brevundimonas sp. KR013 } \\
\text { Pseudomonas fluorescens CR3 } \\
\text { Pseudomonas sp. KR017 } \\
\text { Rhizobium leguminosarum } \\
\quad \text { bv. trifolii NZP561 }\end{array}$ & None & Cadmium & Culture media & - Sequestered Cd directly from solution & Robinson et al. (2001) \\
\hline $\begin{array}{l}\text { Kluyvera ascorbata SUD165 } \\
\text { Kluyvera ascorbata SUD165/26 }\end{array}$ & $\begin{array}{l}\text { Indian } \\
\text { mustard } \\
\text { Canola } \\
\text { Tomato }\end{array}$ & $\begin{array}{l}\text { Nickel, } \\
\text { lead, zinc }\end{array}$ & $\begin{array}{l}\text { Pot experiments in } \\
\text { growth chamber }\end{array}$ & $\begin{array}{l}\text { - Both strains decreased some plant growth inhibition } \\
\text { by heavy metals } \\
\text { - No increase of metal uptake with either } \\
\text { strain over noninoculated plants }\end{array}$ & Burd et al. (2000) \\
\hline $\begin{array}{l}\text { Mesorhizobium huakuii subsp. } \\
\quad \text { rengei } \mathrm{B} 3\end{array}$ & $\begin{array}{l}\text { Astragalus } \\
\text { sinicus }\end{array}$ & Cadmium & Hydroponics & $\begin{array}{l}\text { - Expression of } \mathrm{PCS}_{A t} \text { gene increased ability of cells } \\
\text { to bind } \mathrm{Cd}^{2+} \text { approximately 9- to } 19 \text {-fold }\end{array}$ & Sriprang et al. (2003) \\
\hline
\end{tabular}


1994). Leong (1986) reported that heavy metals in soils could stimulate the production of siderophores. Pishchik et al. (2005) mathematically simulated the succession of events under conditions of cadmium stress which began with the synthesis of phytohormones (IAA and ethylene) and ended with higher uptake of ions by the roots. The possible explanation might be the synthesis of these compounds which were not found in the organic-contaminated systems is stimulated by heavy metals or that they don't function in degradation of organic contaminants. But these processes may be hindered due to the high concentration of heavy metals (Dell'Amico et al., 2005), because many rhizobacteria could not survive in such a high heavy metal concentration environment. The $\mathrm{pH}$ and the bacterial species present have also effects on the degree of sequestration (Robinson et al., 2001). Dell'Amico et al. (2005) reported when living in association with rhizosphere soils and rhizoplane, many different microbial communities are able to withstand the high heavy metal concentrations, but the mechanism of metal tolerance and the possible metal transforming capacities of the metal-resistant PGPR need to be further studied.

\subsection{Facilitating metal phase transformation and uptake}

Soil microorganisms are known to affect the metal mobility and availability to the plant, through acidification, and redox changes or by producing iron chelators and siderophores for ensuring the iron availability, and/or mobilizing the metal phosphates (Abou-Shanab et al., 2003; Burd et al., 2000; Guan et al., 2001). For example, EDTA and EDGA were considered as good chelators to enhance the metal availability to plants, whereas these chelators may lead to side-effects such as metal leaching and low microbial activity (Ernst, 1996; Römkens et al., 2002). Another problem that affects the metal uptake is the existing phase of metal. A large proportion of metal contaminants are unavailable for the root uptake by plants, because heavy metals in soils are generally bound to organic and inorganic soil constituents, or alternatively, present as insoluble precipitates. Hence, how to increase the availability of metals to plants in soils is critical for the success of phytoremediation (Ernst, 1996; Kukier et al., 2004). Abou-Shanab et al. (2006) studied the effect of certain rhizobacteria on nickel uptake. They indicated that rhizobacteria facilitated the release of $\mathrm{Ni}$ from the non-soluble phases in the soil, thus enhancing the availability of Ni to Alyssum murale. There is a need to improve our understanding of the mechanisms involved in transfer and mobilization of heavy metals by the rhizosphere microbes. A possible explanation might be acid and siderophore production and phosphate solubilization.

\subsection{Endophytic effects and concerted action}

Endophytes are microorganisms colonized to an intimate niche of the plant and are beneficial for the growth and health of the host (Lodewyckx et al., 2002). Using both cultivation and cultivation-independent techniques, Idris et al. (2004) investigated the endophytes and rhizobacteria with Thlaspi goesingense, a hyperaccumulator of Nickel. Generally, most of the endophytes were cultivation-independent and tolerated higher concentration of $\mathrm{Ni}$ than rhizosphere bacteria. Although this system is promising in heavy metal remediation, the mechanisms by which endophytes promote metal accumulation are not well understood yet and the application of cultivation-independent microbe is very difficult.

Gray and Smith (2005) divided PGPR into two groups according to their residing sites: iPGPR (i.e., symbiotic bacteria), which live inside the plant cells, produce nodules and are localized inside those specialized structures, and ePGPR (i.e., free-living rhizobacteria), which live outside the plant cells and do not produce nodules, but still prompt the plant growth. The best known iPGPR are rhizobia, but they are restricted to nodules in leguminous plants (Sriprang et al., 2003). Kamnev et al. (2005) studied a wild-type strain Sp245 of rhizobacterium Azospirillum brasilense, which has been proven to be capable of colonizing both interior and exterior of the plant root (i.e., a facultative endophyte), while other strains can colonize the root surface only. They compared the responses of Sp245 and other strains to several heavy metals $\left(\mathrm{Co}^{2+}, \mathrm{Cu}^{2+}\right.$ and $\left.\mathrm{Zn}^{2+}\right)$. The response of the endophytic strain $\mathrm{Sp} 245$ to the heavy metal uptake was found much less pronounced than the nonendophytic. They supposed the dissimilarities in their behaviour caused by the different adaptation abilities of these strains to the stress conditions due to their different ecological status.

Besides symbiotic bacteria, arbuscular mycorrhizal fungi (AMF) form symbiotic relationships with $80-90 \%$ land plants (Brundrett, 2002). These fungi may also facilitate the uptake and transfer of heavy metal to the roots (Leyval et al., 1997). In addition, AMF as well as quantities of other microbes also exist in the rhizosphere, such as P-solubilizing bacteria and mycorrhizal-helping bacteria (MHB) initiate a concerted action when a particular population density is achieved, i.e., quorum sensing (Khan, 2005). This phenomenon expands the environmental signals to a larger range (Daniels et al., 2004). The involvement of fungi is beyond the scope in our review and will not be further discussed.

\subsection{Genetically-engineered approach}

Metallothioneins (MTs) (Robinson et al., 1993; Yoshida et al., 2002) and phytochelatins (PCs) (Cobbett, 2000; Rauser, 1995) are naturally occurring examples of peptides that can effectively bind a wide range of heavy metals with high affinity. The structure of PCs can be represented by $(\gamma-\mathrm{Glu}-\mathrm{Cys})_{\mathrm{n}}-\mathrm{Gly}$, and due to their repeating Glu-Cys moieties, PCs are more attractive to heavy metals as they offer the higher metal-binding capacity than MTs (Mehra and Mulchandani, 1995). Sriprang et al. (2003) introduced Arabidopsis thaliana gene for phytochelatin synthase $\left(\mathrm{PCS} ; \mathrm{PCS}_{A t}\right)$ into Mesorhizobium huakuii subsp. rengei strain $\mathrm{B} 3$ and then established the symbiosis between M. huakuii subsp. rengei strain $\mathrm{B} 3$ and Astragalus sinicus. The gene was expressed to produce PCs and accumulate $\mathrm{Cd}^{2+}$, under the control of bacteroid-specific promoter, the nifH gene (Perret et al., 1999).

However, the presence of $\gamma$ bond between Glu and Cys indicates that these peptides must be synthesized enzymatically. An attractive alternative is to employ the synthetic 
phytochelatins (ECs), which are protein analogs of PCs with similar heavy-metal-binding affinities that can be easily produced from a synthetic DNA template by the standard molecular cloning techniques (Wu et al., 2006a). This symbiotic relationship was established between a Pseudomonas putida strain and sunflower seedlings. We can utilize different engineered rhizobacteria to remediate complex contaminated soil, which is more flexible than the rhizobia-legume relationship.

Besides transition of gene between bacteria, transgenic plants have been constructed for higher remediation efficiency (Grckho et al., 2000; Nie et al., 2002; Stearns et al., 2005). The expression of ACC deaminase in the plant exhibits several advantages against in the bacteria: (1) during the initial stages of seed germination, the bacterial ACC deaminase activity is likely to be much lower than the activity in transgenic plants (Nie et al., 2002); (2) it can constantly stimulate plant growth, which leads to a higher metal accumulation; (3) in some cases an increase in the shoot/root ratio (Grckho et al., 2000); (4) prompting metal uptake of certain fast-growing plants for the substitution of slow-growing hyperaccumulators (Stearns et al., 2005).

\section{Conclusion}

The recent researches of PGPR on the remediation of contaminated soils show a brilliant prospect for the successive studies. For example, the combined use of PGPR and specific contaminant-degrading bacteria can successfully remove complex contaminants (Huang et al., 2005). The application of certain rhizobacteria can increase the uptake of $\mathrm{Ni}$ from soils by changing its phase (Abou-Shanab et al., 2006). Also, the manipulation of genetic-engineering technologies greatly expands the extension and degree of bioremediation.

Breakthroughs in this field are still very difficult to achieve before the following critical problems are solved. (1) Although many successful remediation cases with PGPR are reported, we still know little about the process mechanism and how PGPR really interact with plant roots and other bacteria. (2) Almost all the previous works on bioremediation with PGPR were carried out in lab or greenhouse. How the remediation effects will change in the field, which is a more complicated ecosystem, requires the support of more in situ experiments. (3) The application scope is currently limited because the existing PGPR can only colonize certain plants. (4) Although some PGPR can increase the tolerance of plants to contaminants, the PGPR-plant system cannot survive in comparatively extreme environments such as with high concentrations of heavy metals. How to construct a more robust system for remediation brings new challenges to us.

\section{References}

Abou-Shanab RA, Delorme TA, Angle JS, Chaney RL, Ghanem K, Moawad H. Phenotypic characterization of microbes in the rhizosphere of Alyssum murale. Int J Phytoremediation 2003;5:367-79.

Abou-Shanab RAI, Angle JS, Chaney RL. Bacterial inoculants affecting nickel uptake by Alyssum murale from low, moderate and high Ni soils. Soil Biol Biochem 2006;38:2882-9.
Ajithkumar PV, Gangadhara KP, Manilal P, Kunhi AAM. Soil inoculation with Pseudomonas aeruginosa 3MT eliminates the inhibitory effect of 3-chloroand 4-chlorobenzoate on tomato seed germination. Soil Biol Biochem 1998;30:1053-9.

Alvey S, Crowley DE. Survival and activity of an atrazine-mineralizing bacterial consortium in rhizosphere soil. Environ Sci Technol 1996;30:1596-603.

Barac T, Taghavi S, Borremans B, Provoost A, Oeyen L, Colpaert JV. Engineered endophytic bacteria improve phytoremediation of water-soluble, volatile, organic pollutants. Nat Biotechnol 2004;22:583-8.

Bashan Y, Levanony H. Current status of Azospirillum inoculation technology: Azospirillum as a challenge for agriculture. Can J Microbiol 1990;36:591-608.

Belimov AA, Dietz KJ. Effect of associative bacteria on element composition of barley seedlings grown in solution culture at toxic cadmium concentrations. Microbiol Res 2000;155:113-21.

Belimov AA, Hontzeas N, Safronova VI, Demchinskaya SV, Piluzza G, Bullitta S, et al. Cadmium-tolerant plant growth-promoting rhizobacteria associated with the roots of Indian mustard (Brassica juncea L. Czern.). Soil Biol Biochem 2005;37:241-50.

Belimov AA, Safronova VI, Sergeyeva TA, Egorova TN, Matveyeva VA, Tsyganov VE, et al. Characterization of plant growth promoting rhizobacteria isolated from polluted soils and containing 1-aminocyclopropane-1-carboxylate deaminase. Can J Microbiol 2001;47:642-52.

Bradford MM. A rapid and sensitive method for the quantitation of microgram quantities of protein utilizing the principle of protein-dye binding. Anal Biochem 1976;72:248-54.

Brazil GM, Kenefick L, Callanan M, Haro A, de Lorenzo V, Dowling DN. Construction of a rhizosphere pseudomonad with potential to degrade polychlorinated biphenyls and detection of $b p h$ gene expression in the rhizosphere. Appl Environ Microbiol 1995;61:1946-52.

Brookes PC, McGrath SP. Effects of metal toxicity on the size of the soil microbial biomass. J Soil Sci 1984;35:341-6.

Brundrett MC. Coevolution of roots and mycorrhizas of land plants. New Phytol 2002;154:275-304.

Burd GI, Dixon DG, Glick BR. A plant growth promoting bacterium that decreases nickel toxicity in plant seedlings. Appl Environ Microbiol 1998;64:3663-8.

Burd GI, Dixon DG, Glick BR. Plant growth-promoting bacteria that decrease heavy metal toxicity in plants. Can J Microbiol 2000;46:237-45.

Çakmakçi R, Dönmez F, Aydm A, Şahin F. Growth promotion of plants by plant growth-promoting rhizobacteria under greenhouse and two different field soil conditions. Soil Biol Biochem 2006;38:1482-7.

Chaudri AM, McGrath SP, Giller KE, Rietz E, Sauerbeck DR. Enumeration of indigenous Rhizobium leguminosarum biovar trifolii in soils previously treated with metal-contaminated sewage sludge. Soil Biol Biochem 1993;25:301-9

Chekol T, Vough LR, Chaney R. Phytoremediation of polychlorinated biphenylcontaminated soils: the rhizosphere effect. Environ Int 2004;30:799-804.

Cobbett CS. Phytochelatins and their roles in heavy metal detoxification. Plant Physiol 2000;123:825-32.

Compant S, Duffy B, Nowak J, Clement C, Barka EA. Use of plant growthpromoting bacteria for biocontrol of plant diseases: principles, mechanisms of action, and future prospects. Appl Environ Microbiol 2005;71:4951-9.

Crowley DE, Brennerova ME, Irwin C, Brenner V, Focht DD. Rhizosphere effects on biodegradation of 2,5-dichlorobenzoate by a bioluminescent strain of rootcolonizing Pseudomonas fluorescens. FEMS Microbiol Ecol 1996;20:79-89.

Daniels R, Vanderleyden J, Michiels J. Quorum sensing and swarming migration in bacteria. FEMS Microbiol Rev 2004;28:261-89.

Deikman J. Molecular mechanisms of ethylene regulation of gene transcription. Physiol Plant 1997;100:561-6.

Dell'Amico E, Cavalca L, Andreoni V. Analysis of rhizobacterial communities in perennial Graminaceae from polluted water meadow soil, and screening of metal-resistant, potentially plant growth-promoting bacteria. FEMS Microbiol Ecol 2005;52:153-62.

Donnelly KP, Hegde SR, Fletcher SH. Growth of PCB-degrading bacteria on compounds from photosynthetic plants. Chemosphere 1994;28:981-8.

Ernst WHO. Bioavailability of heavy metals and decontamination of soil by plants. Appl Geochem 1996;11:163-7.

Fletcher JS, Hedge RS. Release of phenols by perennial plant roots and their potential importance in bioremediation. Chemosphere 1995;31:3009-16. 
Fliessbach A, Martens R, Reber HH. Soil microbial biomass and microbial activity in soils treated with heavy metal contaminated sewage sludge. Soil Biol Biochem 1994;26:1201-5.

Frostegård A, Tunlid A, Bååth E. Phospholipid fatty acid composition, biomass and activity of microbial communities from two soil types experimentally exposed to different heavy metals. Appl Environ Microbiol 1993;59:3605-17.

Frostegård A, Tunlid A, Bååth E. Changes in microbial community structure during long-term incubation in two soils experimentally contaminated with metals. Soil Biol Biochem 1996;28:55-63.

Gianfreda L, Rao MA. Potential of extra cellular enzymes in remediation of polluted soils: a review. Enzyme Microb Technol 2004;35:339-54.

Glick BR. The enhancement of plant growth by free-living bacteria. Can J Microbiol 1995;41:109-17.

Glick BR. Phytoremediation: synergistic use of plants and bacteria to clean up the environment. Biotechnol Adv 2001;21:383-93.

Gray EJ, Smith DL. Intracellular and extracellular PGPR: commonalities and distinctions in the plant-bacterium signaling processes. Soil Biol Biochem 2005;37:395-412.

Grckho VP, Filby B, Glick BR. Increased ability of transgenic plants expressing the bacterial enzyme ACC deaminase to accumulate $\mathrm{Cd}, \mathrm{Co}, \mathrm{Cu}, \mathrm{Ni}, \mathrm{Pb}$, and Zn. J Biotechnol 2000;81:45-53.

Guan LL, Kanoh K, Kamino K. Effect of exogenous siderophores on iron uptake activity of marine bacteria under ironlimited conditions. Appl Environ Microbiol 2001;67:1710-7.

Guo JH, Qi HY, Guo YH, Ge HL, Gong LY, Zhang LX. Biocontrol of tomato wilt by plant growth-promoting rhizobacteria. Biol Control 2004;29:66-72.

Hall JA, Peirson D, Ghosh S, Glick BR. Root elongation in various agronomic crops by the plant growth promoting rhizobacterium Pseudomonas putida GR12-2. Isr J Plant Sci 1996;44:37-42.

Hall JL. Cellular mechanisms for heavy metal detoxification and tolerance. J Exp Bot 2002;53:1-11.

Hallberg KB, Johnson DB. Microbiology of a wetland ecosystem constructed to remediate mine drainage from a heavy metal mine. Sci Total Environ 2005;338:53-66.

Hallman J, Quadt-Hallman A, Mahafee WF, Kloepper JW. Bacterial endophytes in agricultural crops. Can J Microbiol 1997;43:895-914.

Huang XD, El-Alawi Y, Gurska J, Glick BR, Greenberg BM. A multi-process phytoremediation system for decontamination of persistent total petroleum hydrocarbons (TPHs) from soils. Microchem J 2005;81:139-47.

Huang XD, El-Alawi Y, Penrose DM, Glick BR, Greenberg BM. Responses of three grass species to creosote during phytoremediation. Environ Pollut 2004a;130:453-63.

Huang XD, El-Alawi Y, Penrose DM, Glick BR, Greenberg BM. A multiprocess phytoremediation system for removal of polycyclic aromatic hydrocarbons from contaminated soils. Environ Pollut 2004b;130:465-76.

Idris R, Trifonova R, Puschenreiter M, Wenzel WW, Sessitsch A. Bacterial communities associated with flowering plants of the Ni hyperaccumulator Thlaspi goesingense. Appl Environ Microbiol 2004;70:2667-77.

Jetiyanon K, Kloepper JW. Mixtures of plant growth-promoting rhizobacteria for induction of systemic resistance against multiple plant diseases. Biol Control 2002;24:285-91

Kamnev AA, Tugarova AV, Antonyuk LP, Tarantilis PA, Polissiou MG, Gardiner PHE. Effects of heavy metals on plant-associated rhizobacteria: comparison of endophytic and non-endophytic strains of Azospirillum brasilense. J Trace Elem Med Biol 2005;19:91-5.

Kao PH, Huang CC, Hseu ZY. Response of microbial activities to heavy metals in a neutral loamy soil treated with biosolid. Chemosphere 2006;64:63-70.

Khan AG. Role of soil microbes in the rhizospheres of plants growing on trace metal contaminated soils in phytoremediation. J Trace Elem Med Biol 2005; 18:355-64

Kloepper JW, Schroth MN. Plant growth-promoting rhizobacteria on radishes. Proceedings of the Fourth International Conference on Plant Pathogen Bacteria, vol. 2. INRA; 1978. p. 879-82.

Koomen I, McGrath SP, Giller KE. Mycorrhizal infection of clover is delayed in soils contaminated with heavy metals from past sewage sludge applications. Soil Biol Biochem 1990;22:871-3.

Kukier U, Peters CA, Chaney RL, Angle JS, Roseberg RJ. The effect of pH on metal accumulation in two Alyssum species. J Environ Qual 2004;32:2090-102.
Leong J. Siderophores: their biochemistry and possible role in control of plant pathogens. Annu Rev Phytopathol 1986;24:187-209.

Leyval C, Turnau K, Haselwandter. Effect of heavy metal pollution on mycorrhizal colonization and function: physiological, ecological and applied aspects. Mycorrhiza 1997;7:139-53.

Liste $\mathrm{HH}$, Alexander M. Accumulation of phenanthrene and pyrene in rhizosphere soil. Chemosphere 2000;40:11-4.

Lodewyckx C, Vangronsfeld J, Porteous F, Moore ERB, Taghavi S, Mergeay M, et al. Endophytic bacteria and their potential applications. Crit Rev Plant Sci 2002;21:563-606.

Lucas García JA, Domenech J, Santamaría C, Camacho M, Daza A, Gutierrez Mañero FJ. Growth of forest plants (pine and holm-oak) inoculated with rhizobacteria: relationship with microbial community structure and biological activity of its rhizosphere. Environ Exp Bot 2004a;52:239-51.

Lucas García JA, Probanza A, Ramos B, Barriuso J, Gutierrez Mañero FJ. Effects of inoculation with plant growth promoting rhizobacteria (PGPRs) and Sinorhizobium fredii on biological nitrogen fixation, nodulation and growth of Glycine max cv. Osumi. Plant Soil 2004b;267:143-53.

Lucy M, Reed E, Glick BR. Applications of free living plant growth-promoting rhizobacteria. Antonie van Leeuwenhoek 2004;86:1-25.

Mehra RK, Mulchandani P. Glutathione-mediated transfer of $\mathrm{Cu}(\mathrm{I})$ into phytochelatins. Biochem J 1995;307:697-705.

Morgan PW, Drew CD. Ethylene and plant responses to stress. Physiol Plant 1997;100:620-30.

Muratova AY, Turkovskaya OV, Antonyuk LP, Makarov OE, Pozdnyakova LI, Ignatov VV. Oil-oxidizing potential of associative rhizobacteria of the genus Azospirillum. Microbiology 2005;74:210-5.

Narasimhan K, Basheer C, Bajic VB, Swarup S. Enhancement of plant-microbe interactions using a rhizosphere metabolomics-driven approach and its application in the removal of polychlorinated biphenyls. Plant Physiol 2003;132:146-53.

Nie L, Shah S, Burd GI, Dixon DG, Glick BR. Phytoremediation of arsenate contaminated soil by transgenic canola and the plant growth-promoting bacterium Enterobacter cloacae CAL2. Plant Physiol Biochem 2002;40: 355-61.

Normander B, Hendriksen NB, Nybroe O. Green fluorescent protein-marked Pseudomonas fluorescens: localization, viability, and activity in the natural barley rhizosphere. Appl Environ Microbiol 1999;65:4646-51.

Okon Y, Labandera-Gonzalez CA. Agronomic applications of Azospirillum: an evaluation of 20 years world-wide field inoculation. Soil Biol Biochem 1994;26:1591-601.

Pattern CL, Glick RB. Bacterial biosynthesis of indole-3-acetic acid. Can J Microbiol 1996;42:207-20.

Penrose DM, Glick BR. Levels of 1-aminocyclopropane-1-carboxylic acid (ACC) in exudates and extracts of canola seeds treated with plant growthpromoting bacteria. Can J Microbiol 2001;47:368-72.

Perret X, Freiberg C, Rosenthal A, Broughton WJ, Fellay R. High-resolution transcriptional analysis of the symbiotic plasmid of Rhizobium sp. NGR234. Mol Microbiol 1999;32:415-25.

Pishchik VN, Vorob'ev NI, Provorov NA. Experimental and mathematical simulation of population dynamics of rhizospheric bacteria under conditions of cadmium stress. Microbiology 2005;74:735-40.

Prokop G, Schamann M, Edelgaard I. Management of contaminated sites in western Europe. Copenhagen, Denmark: European Environment Agency; 2000. p. 171.

Raj SN, Deepak SA, Basavaraju P, Shetty HS, Reddy MS, Kloepper JW. Comparative performance of formulations of plant growth promoting rhizobacteria in growth promotion and suppression of downy mildew in pearl millet. Crop Prot 2003;22:579-88.

Rauser WE. Phytochelatins and related peptides. Plant Physiol 1995;109:1141-9.

Reed MLE, Glick BR. Growth of canola (Brassica napus) in the presence of plant growth-promoting bacteria and either copper or polycyclic aromatic hydrocarbons. Can J Microbiol 2005;51:1061-9.

Reed MLE, Warner B, Glick BR. Plant growth-promoting bacteria facilitate the growth of the common reed Phragmites australis in the presence of copper or polycyclic aromatic hydrocarbons. Curr Microbiol 2005;51:425-9.

Robinson B, Russell C, Hedley M, Clothier B. Cadmium adsorption by rhizobacteria: implications for New Zealand pastureland. Agric Ecosyst Environ 2001;87:315-21. 
Robinson NJ, Tommey AM, Kuske C, Jackson PJ. Plant metallothioneins. Biochem J 1993;295:1-10.

Römkens P, Bouwman L, Japenga J, Draaisma C. Potentials and drawbacks of chelate-enhanced phytoremediation of soils. Environ Pollut 2002;116:109-21.

Safronova VI, Stepanok VV, Engqvist GL, Alekseyev YV, Belimov AA. Rootassociated bacteria containing 1-aminocyclopropane-1-carboxylate deaminase improve growth and nutrient uptake by pea genotypes cultivated in cadmium supplemented soil. Biol Fertil Soils 2006;42:267-72.

Saleh S, Huang XD, Greenberg BM, Glick BR. Phytoremediation of persistent organic contaminants in the environment. In: Singh A, Ward O, editors. Soil Biology: vol. 1. Applied Bioremediation and Phytoremediation. Berlin: Springer-Verlag; 2004. p. 115-34.

Sandaa RA, Torsvik V, Enger $\varnothing$. Analysis of bacterial communities in heavy metal-contaminated soils at different levels of resolution. FEMS Microbiol Ecol 1999;30:237-51.

Saravanakumar D, Vijayakumar C, Kumar N, Samiyappan R. PGPR-induced defense responses in the tea plant against blister blight disease. Crop Prot, in press. doi:10.1016/j.cropro.2006.05.007.

Siciliano SD, Germida JJ. Bacterial inoculants of forage grasses that enhance degradation of 2-chlorobenzoic acid in soil. Environ Toxicol Chem 1997;16:1098-104.

Siciliano SD, Germida JJ. Enhanced phytoremediation of chlorobenzoates in rhizosphere soil. Soil Biol Biochem 1999;31:299-305.

Siddiqui ZA, Mahmood I. Effects of rhizobacteria and root symbionts on the reproduction of Meloidogyne javanica and growth of chickpea. Bioresour Technol 2001;79:41-5.

Sriprang R, Hayashi M, Ono H, Takagi M, Hirata K, Murooka Y. Enhanced accumulation of $\mathrm{Cd}^{2+}$ by a Mesorhizobium sp. transformed with a gene from Arabidopsis thaliana coding for phytochelatin synthase. Appl Environ Microbiol 2003;69:1791-6.

Stearns JC, Shah S, Dixon DG, Greenberg BM, Glick BR. Tolerance of transgenic canola expressing 1-aminocyclopropane-carboxylic acid deam- inase to growth inhibition by nickel. Plant Physiol Biochem 2005;43: 701-8.

Sturz AV, Christie BR, Nowak J. Bacterial endophytes: potential role in developing sustainable systems of crop production. Crit Rev Plant Sci 2000;19:1-30.

Timmis KN, Pieper DH. Bacteria designed for bioremediation. Trends Biotechnol 1999;17:200-4.

Umrania VV. Bioremediation of toxic heavy metals using acidothermophilic autotrophes. Bioresour Technol 2006;97:1237-42.

Villacieros M, Whelan C, Mackova M, Molgaard J, Sanchez-Contreras M, Lloret J. Polychlorinated biphenyl rhizoremediation by Pseudomonas fluorescens F113 derivatives, using a Sinorhizobium meliloti nod system to drive $b p h$ gene expression. Appl Environ Microbiol 2005;71:2687-94.

Welbaum G, Sturz AV, Dong Z, Nowak J. Fertilizing soil microorganisms to improve productivity of agroecosystems. Crit Rev Plant Sci 2004;23:175-93.

$\mathrm{Wu} \mathrm{CH}$, Wood TK, Mulchandani A, Chen W. Engineering plant-microbe symbiosis for rhizoremediation of heavy metals. Appl Environ Microbiol 2006a;72:1129-34

Wu SC, Cheung KC, Luo YM, Wong MH. Effects of inoculation of plant growth-promoting rhizobacteria on metal uptake by Brassica juncea. Environ Pollut 2006b;140:124-35.

Yee DC, Maynard JA, Wood TK. Rhizoremediation of trichloroethylene by a recombinant, root-colonizing Pseudomonas fluorescens strain expressing toluene ortho-monooxygenase constitutively. Appl Environ Microbiol 1998;64:112-8.

Yoshida N, Kato T, Yoshida T, Ogawa K, Yamashita M, Murooka Y. Bacteriumbased heavy metal biosorbents: enhanced uptake of cadmium by Escherichia coli expressing a metallothionein fused to beta-galactosidase. BioTechniques 2002;32:551-6.

Zaidi S, Usmani S, Singh BR, Musarrat J. Significance of Bacillus subtilis strain SJ-101 as a bioinoculant for concurrent plant growth promotion and nickel accumulation in Brassica juncea. Chemosphere 2006;64:991-7. 